\title{
Preservation and Development Strategies of Gorontalo's Local Culture through Gorontalo Cultural Digital Repository Application
}

\author{
ARIP MULYANTO, ${ }^{1}$ MUKHLISULFATIH LATIEF, ${ }^{2}$ MANDA ROHANDI, ${ }^{3}$ SUPRIYADI ${ }^{4}$ \\ 1,2,3. Technical Information Department, Faculty of Engineering, Gorontalo State University, Indonesia \\ 4 Indonesian Language and Literature Department, Faculty of Arts and Culture, Gorontalo State University, Indonesia \\ E-mail:arip.mulyanto@ung.ac.id
}

Penelitian ini bertujuan untuk menerapkan strategi pemertahanan dan pengembangan budaya lokal Gorontalo melalui sebuah aplikasi yang dapat menyimpan dan menampilkan hasil digitalisasi budaya lokal Gorontalo berbasis websiteyang disebut "Repository digital budaya Gorontalo".Aplikasi repositori digital budaya Gorontalo menyediakan informasi tentang budaya Gorontalo seperti adat istiadat, tari-tarian, tempat bersejarah dan artefak budaya Gorontalo dalam bentuk video, gambar dan teks.Metode yang digunakan dalam penelitian ini adalah metode terapan dengan prosedur penelitian:1) Eksplorasi,yaitu mengidentifikasi dan menganalisis data-data budaya lokal Gorontalo yang meliputi adat istiadat Gorontalo, tari-tarian, tempat bersejarah dan artefak budaya Gorontalo. 2) Pengembangan koleksi Digital budaya Lokal Gorontalo, yaitu mendigitalisasi hasil indentifikasi dan analisis data-data budaya lokal Gorontalo. 3)Pengembangan aplikasi Repository Digital Budaya Gorontalo.Dari hasil penelitian didapatkan: 1) Eksplorasi, adat istiadat Gorontalo terdiri dari empat aspek penting, yaitu adat penyambutan tamu, adat penobatan, adat perkawinan dan adat pemakaman. Tempat bersejarah yang berada di Gorontalo lebih kurang terdapat 20 tempat bersejarah.Adapun tari-tarian terdapat 4 tari-tarian yang biasanya dipentaskan dalam perayaan adat Gorontalo. 2)Digitalisasi kegiatan budaya seperti upacara adat, tari-tarian dan profil tempat bersejarah dilakukan dengan menggunakan camcorder untuk menghasilkan format video. Adapun untuk gambar/foto dilakukan dengan menggunakan camera digital yang kemudian disimpan dengan format JPEG. 3)Pengembangan Aplikasi Repository Budaya Gorontalo yang dikembangkan memiliki beberapa fungsi yang terdiri atas tiga aktivitas utama: memasukan data budaya, menentukan reviewer untuk data budaya dan me-review data budayayang telah di masukan.

This study aims to implement a strategy of preservation and development of Gorontalo's local culture through a web based application that can store and display the digitizing results of Gorontalo's local culture called "Gorontalo cultural digital repository". The Gorontalo cultural digital repository provides information about the cultures in Gorontalo such as the mores, dances, historic sites and Gorontalo's cultural artifacts in the form of video, images and text. The method used in this research is applied method with research procedures by: 1) Exploration, is to identify and analyze the data of local Gorontalo's culture that covers Gorontalo's mores, dances historic sites and Gorontalo's cultural artifacts. 2) The development of Gorontalo cultural digital collection, which digitize the identification and analysis result of Gorontalo's local culture. 3) Gorontalo Cultural Digital Repository application development. From the result of the research found: 1) Exploration the mores of Gorontalo consist of four important aspects, namely customary welcoming guests, traditional coronation, marriage customs and funeral customs. There are more or less 20 historic sites located in Gorontalo. There are four dances that are usually performed in the customary celebration in Gorontalo. 
2) The Digitization of cultural activities such as ceremonies, dances and historic sites profile is done by using the camcorder to produce a video format. As for the image / picture is done by using a digital camera which is then stored in JPEG format. 3) The development of Gorontalo cultural repository application that was developed has several functions which consists of three main activities: namely entering the cultural data, determining reviewer for cultural data and reviewing the cultural data that has been input.

Keywords: Preservation and development strategies, Gorontalo's local culture, Gorontalo Cultural Digital Repository Application.

Culture is a habit or a way of living together as a whole which is owned by the community and handed down from generation to generation. Culture can be religious rules, customs, languages, tools, clothing, dances, buildings, legends, food and others. According Kayam (in Said et al, 2009), culture is the result of continuous efforts of people in the community ties in creating the necessary infrastructures to meet the challenges of life. Said et al, (2009) states that local wisdom can not be separated from culture form, where the form of the culture itself is divided into three, namely (1) the culture is a complexity of thoughts, ideas, values, rules and so on, (2) culture as the complexity of the pattern of human behavior in society, and (3) culture as objects of human works. Legends are part of the first form of culture, because take the form of a collection of abstract ideas that can not be touched and intangible. Customs is the second form of culture, because of the form of action or human activity interacting with other human beings according to the manners or rules. Customs are concrete where the activity can be observed and documented. Historic sites are a third form of culture, due to the physical form as a man's work in the form of objects, buildings and others that can be touched and seen

Gorontalo as the area of culture that upholds the values of culture and religion, where the two are inseparable. Cultural integrity and religion are portrayed in the philosophy of life of the Gorontalo people, "Customs hinged in syara", Syara' hinged in Kitabullah ", this was confirmed by custom by King Eyato known as tahuda. Gorontalo culture includes economic systems (subsistence), system of technology (life equipment), the social system, and religious systems (beliefs) in the community. Gorontalo culture as part of the national culture, requires the attention of the government in terms of developing and maintaining the culture, as mandated by the 1945 Constitution article 32, which reads "The Government of Indonesia promotes national culture". In relation to the preservation of culture, we need to realize that the existence of Gorontalo culture as national culture in general is threatened where the transfer of local traditional value of the older generation to the younger generation is halting and even unclear (see Sutjaja, 2006: 3). All this time, the case of inheritance for generations of cultural values in Gorontalo society is done through the culture of "tutur" (speech) in which cultural values are inherited only through words not through writing, this causes a lack of references to Gorontalo culture, either in the form of books of culture and website.

One strategy for preservation and development of culture that can be done is to use information technology such as Website. Website can show results of digitization of culture in the form of video, images, and text that can be accessed online by anyone from generation to generation. According to European Council of Ministers (in Europeanna Strategic Plan, 2014) "Digitalization and online accessibility are the most important in preserving scientific and cultural heritages, and to inspire the creation of new content and to encourage the emergence of new online services". This statement may be interpreted as a facility provided by technology in the preservation and creation of culture. Tecknologicalization in digital form is more easily accepted by the children and youth so that preservation and development of Gorontalo culture can continue.

Preservation of culture such as literature, symbols, dances and others, is mostly in the form of photo 
graphs, drawings and printed books. The overall results of culture are stored at specific institutions, such as printing house, national museum, library of educational institutions and local government libraries. Digitalization of cultural products brings more profits, which all products in the digitization of culture that have been able to be stored, maintained and disseminated to the public known with the term Repository (Lynch, 2003).

The advantage of repository is the huge capacity, ease of data processing and unlimited access to needed information or ideas. Solution or idea offered as preservation strategy and the development of local culture of Gorontalo are through an application that can store and display the results of digitization of website-based local culture of Gorontalo the so-called "digital repository of Gorontalo culture " (Mulyanto, et al, 2014) . The developed application has some functions of journal review application, where the application can accept cultural data input from the user called the contributor and cultural data that can be reviewed by traditional leaders or people who are competent in the field of Gorontalo culture appointed by the government for which the application is implemented.

The focus of discussion in this topic are: 1) cultural data whatever is necessary for digitalization; 2) how to maintain and develop the local culture through the Digital Repository Application of Gorontalo Culture

The offered idea is important to be discussed and followed up, so that local culture of Gorontalo will keep growing and maintained. The loss of cultural values can lead to the extinction of culture so that the next generation can no longer benefit from the values of the culture. Conversely, the implementation of the preservation strategy and the Gorontalo local cultural development will have a positive impact for the next generation where they can learn and maintain cultural values, so as to make the next generation as the cultured and dignified generation. This is an applied research because the results can be applied directly to resolve the problems in the practical region. The object of this study is all the data of the local culture of Gorontalo, such as customs, dances, historic sites and cultural artifacts of Gorontalo. The research was conducted in three basic steps. First, exploration is to identify and analyze all local culture data of Gorontalo covering Gorontalo customs, dances, historic sites and cultural artifacts. Second, the development of digital collection of Gorontalo local culture, which is digitizing the results of identification and analysis of Gorontalo local culture data. Ketiga, Digital Repository application development of Gorontalo culture.

\section{EXPLORATION OF GORONTALO LOCAL CULTURE}

\section{A.Customs of Gorontalo}

According to Abdussamad et al (1985), customs of Gorontalo area consists of four important aspects, namely welcoming guests, coronation, marriage and death. A brief explanation of the four aspects are as follows:

1.The custom of welcoming guests present in the whole Gorontalo region, known as "Uduluwo limo lo pohala'a". Welcoming guests in Gorontalo area is based on (1) existing customs system for generations represented by "maalo kakali, lonto butu auali, to hulia waliwali" (has been fixed, since the beginning, and now applicable), (2) adjustment to the laws of Islam, known as "customary based on syarak and kitabullah The essence of the welcoming guests customary in Gorontalo area is described with the slogan"aadati maa dili-dilito, bolo mopoqaito, aadati maahunti-huntingo, bolo mopodembingo, aadati maa Dutu-Dutu, bolo mopohutu", which means that the custom has been modeled, just to be connected, the custom has been cut, just to be sticked, the custom has existed, just to be implemented. Respect is given not only to parents or elder, tribute is also given to the person who has high position or who is given the mandate to govern, which is a manifestation of etiquette and manners (Daulima, 2006). The meaning of the customary welcoming guests could be seen from several aspects, (1) in terms of people who are welcomed, in which they must respect and apply the habits of people who welcome them. (2) in terms of people who welcome, where welcoming guests is a sign that Gorontalo society is a society that upholds respect to guests, a homage to the guests means respect for yourself and the community, welcoming guests is also evidence of heights, kindness, manners and hospitality of the people of Gorontalo". The custom of welcoming guests is divided into 
two, namely the reception for guests from outside the area and welcoming guests to the person who holds the position as head of government. The steps of welcoming guests from outside the area is divided into six steps: 1) Mopotupalo; 2) Mopobutulo; 3) Mopohuluqo; 4) Mopeelu; 5) Moduqa; 6) Mongabi. The welcoming guests to olongia, Huhuhu, Wulea lo lipu that will be crowned, have the following steps: 1) Mopotupalo; 2) Mopodiambango; 3) Mopobotulo; 4) Mopotuwoto; 5) Mopohuloqo; 6) Mopotilolo; 7) Mopeelu; 8) Moduwa and mengabi is reserved for Moslems.

2. The custom of Coronation is a traditional ceremony held formally and binding when compared with other traditional ceremonies in Gorontalo area. Coronation ceremony is held like a state ceremony, done solemnly and full of greatness. Preparation before the coronation ceremony is carried out in five phases, as follows:

a. Duulohupa wolo taa tombuluwo (deliberations with the one to be crowned)

b. Duulohupa to bubato lo limutu (deliberation of custom stakeholders di Limboto)

c. Baalanga (sending envoys for results of custom stakeholders meeting)

d. Huhama atau toduwo (inviting officials)

e. Duulohupa (summit for preparation)

The steps in the implementation of the corona tion ceremony are performed within 12 (twelve steps, namely (1) Aadati potidungu; 2) Aadati loqu lipu; 3) Aadati loqu yilumo; 4) Mopotihulo; 5) Mopoluwalo; 6) Mopodiam bango; 7) Mopohuloqo; 8) Momulanga; 9) Molahuli; 10) Mongunti; 11) Moduqa; 12) Mongabi.

3. Marriage custom in Gorontalo area is basically similar to other areas in Indonesia. Islamic religion is a cornerstone of customs in Gorontalo area known as the idiom of "customary based on syarak and syarak based on kitabullah". In the implementation of marriage customary in Gorontalo area is strongly influenced by Islamic procedures, both in terms of movement and in decision-making. The essence of traditional marriage in Gorontalo can be seen from different points of view, both from the standpoint of the family, the bride and groom, offspring that will be generated, religion, and customs of society itself. Terms and law in marriage custom in Gorontalo area follow the terms and legal marriage in Islam. The stages of the implementation of marriage are as follows:

a. Mongilala (stages of reviewing the bride)

b. Mohabari (initial visit of the groom parents)

c. Momatata U Piloqotaawa (asks the firmness of the parents of the bride)

d. Motolobalango (woo the bride)

e. Mongaqata Dalalo (smooth out the stages of Molinilo)

f. Molenilo (connecting families of men and women)

g. Momoqu Ngango (announcing to the public about the wedding plans)

h. Stages of bride preparation

i. Modepitaa Maharu (delivery of dowry)

j. Modepitaa Dilonggato (groceries and others to the parents of the bride)

k. Building sabua/ additional building

1. Inviting Wedding Guests

m. Mopotilandahu (betrothing the bride)

n. Motidi (Dancing / wedding dance)

o. Mopotuluhu (the groom sleeps in the house of the bride)

p. Moponika (marriage)

q. Mongakaji (marriage contract)

r. Molomela Taluhu Tabia (cancel ablutions)

s. Mopopipidu (Pairing)

t. Palebohu (Advising the bride and groom)

u. Modelo stages

v. Mopoturuunani

w. Mopotamelo

4. The implementation of the burial customs of the Gorontalo is nearly identical to the implementation of the funeral in another area that has a foundation of Islam. In the implementation of the funeral in Gorontalo area there are four traditional elements that precede the burial process, namely

a. Taluhu ongongalaqa (water from the family)

b. Puqooliyo

c. Mopobulito Huhuloqo (seating arrangement for officials)

d. Mopodidi

After the four traditional elements above have been implemented, then the next stage is the stage before the corpse is delivered into the grave, including digging the grave, mogaraqi stage (awarding title to the corpse), making stretchers, cutting shroud, bathing the corpse, pray for the corpse bodies. The next 
stage is a funeral consisting of carrying corpse, burial, alms, festivity and neighbors of people who are grieving. After the funeral process, a form of social activity is carried out by the neighbors and the bereaved family in the form of entertainment by cooking together at the house of the bereaved family. This activity is known as Hileiya carried out during the prayer for the souls of the dead. Other forms of entertainment are also provided by the neighbors, known as Dulialo. Dulialo is divided into three, namely advice, materials and games. The days of praying for the souls held five times, i.e on the first day, the third day, the seventh day, the twentieth and fortieth day.

\section{B. Historic Sites in Gorontalo}

Gorontalo is an area rich in history and historical heritage, ranging from historical remains before colonization until heritage of colonial history. Historic sites is one manifestation of the third culture, where historic sites are the work of people who have historical value. Here are some of the historic sites in the province of Gorontalo (Anonymous, 2013):

a. Sacred Tomb of Ju Panggola

b. Sacred Tomb of Pulubunga

c. Sacred Tomb of Ta Ilayabe

d. Sacred Tomb of Haji Buulu

e. Sacred Tomb of Ta Jailoyibuo

f. Sacred Tomb of Hubulo

g. Sacred Tomb of Orang Berdada Tujuh Jengkal (Seven inch chested man)

h. Baya Lo Milate Cave

i. Gorontalo Post Office

j. Soles of Lahilote feet

k. Otanaha Fortress

1. Orange Fortress

m. Traditional House of Dulohupa

n. Traditional House of Gobel

o. Traditional House of Bandayo Pomboide

p. Traditional House of Bele Li Mbui

q. Jembatan Merah (Red Bridge)

r. Taluhu Barakati

s. Mosque of Hunto Sultan Amay

t. Lampu Island

\section{Dances}

Just like other regions in Indonesia, Gorontalo area also has some of the dances very well known by the people of Gorontalo, some of which are:

1. Saronde dance
2. Tidi dance (with all its variations)

3. Dana-dana dance

4. Langga dance, etc.

\section{DEVELOPMENT OF DIGITAL COLLECTION}

Once the data of Gorontalo local culture are completely identified and analyzed, the next step is to build a digital collection. The digital collection is obtained from several sources, namely government agencies, indigenous stakeholders, culturalists / cultural observer, manager of cultural centers or anyone who pursues Gorontalo culture (see Figure $1)$.

Digitalization of cultural activities (see Figure 2) such as ceremonies, dances and profiles of historic places is done using camcorders to produce a video format. As for the picture / photograph are made using a digital camera which are then stored in JPEG format.

\section{Culture Repository Application Development of Gorontalo}

Digital repository application development of Gorontalo culture uses Prototyping system development method (Pressman, 2010). The application developed has several functions with a significant part consisting of three main activities. The three activities are the entering of cultural data, determining reviewers for cultural data and reviewing the data that have been entered.

1. Activities to include cultural data from Contributor

On the activity of entering the data, the user must first register and login as a contributor (see Figure 3 ). If the login is successful, the system will display the pages of cultural data input (see Figure 4). Cultural data included are descriptions of Gorontalo culture in the form of texts, in addition to videos or pictures as complement that have been digitalized by the contributor. The contributors may also at any time re-edit articles that have been entered previously. Cultural data that have been stored in the database are still in pending status (see Figure 5) and then wait for the determination of the reviewer by admin, where the reviewer who will determine whether the data are liable to publish or not / repaired. 


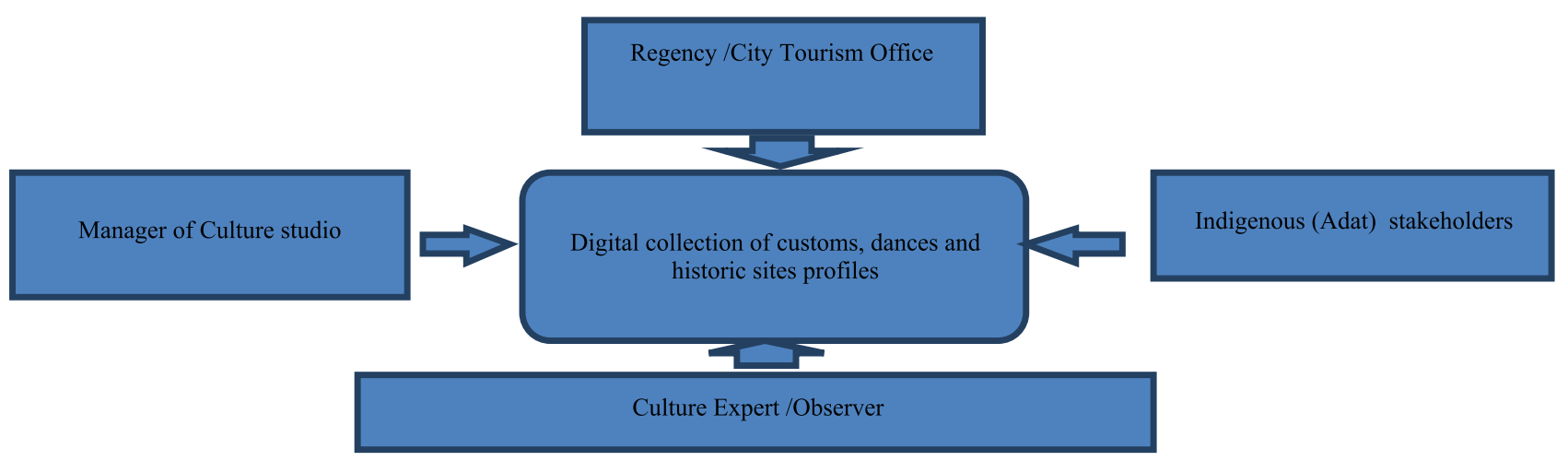

Figure 1. Digital data source of Gorontalo culture (Mulyanto, et.al., 2014)

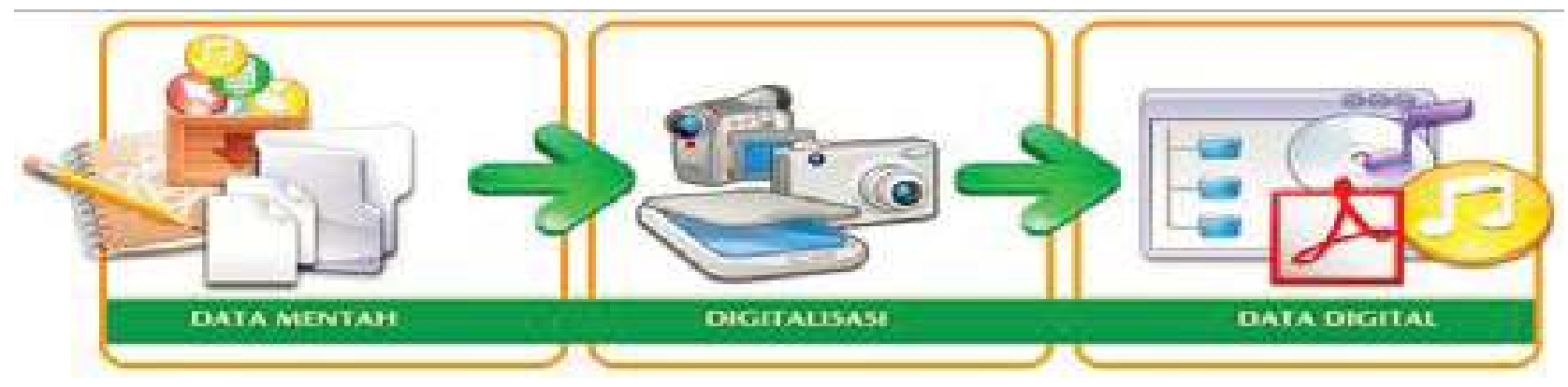

Figure 2. The process of digitizing documents (Rini et al, 2014)

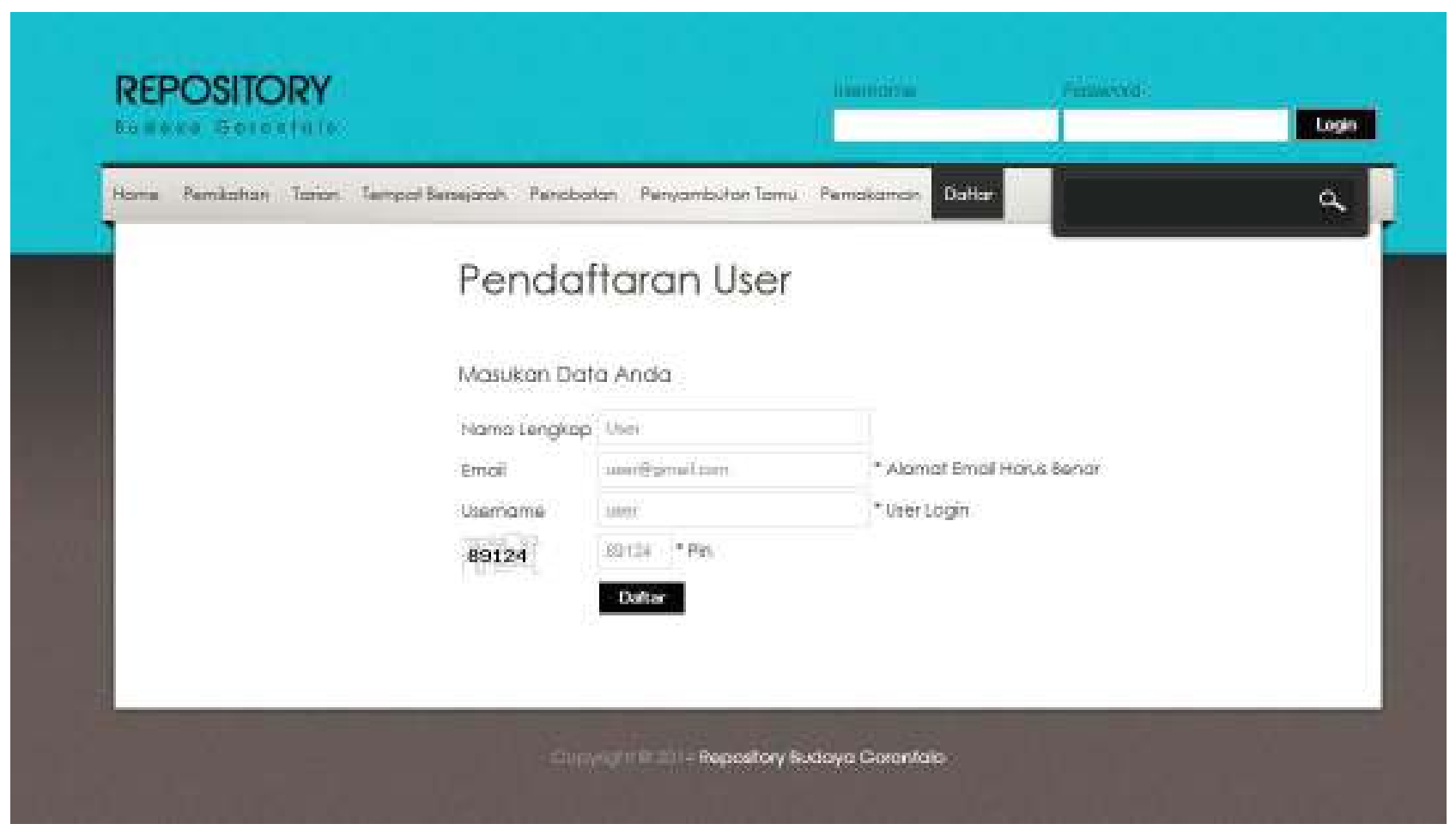

Figure 3. The page for contributor candidate registration 


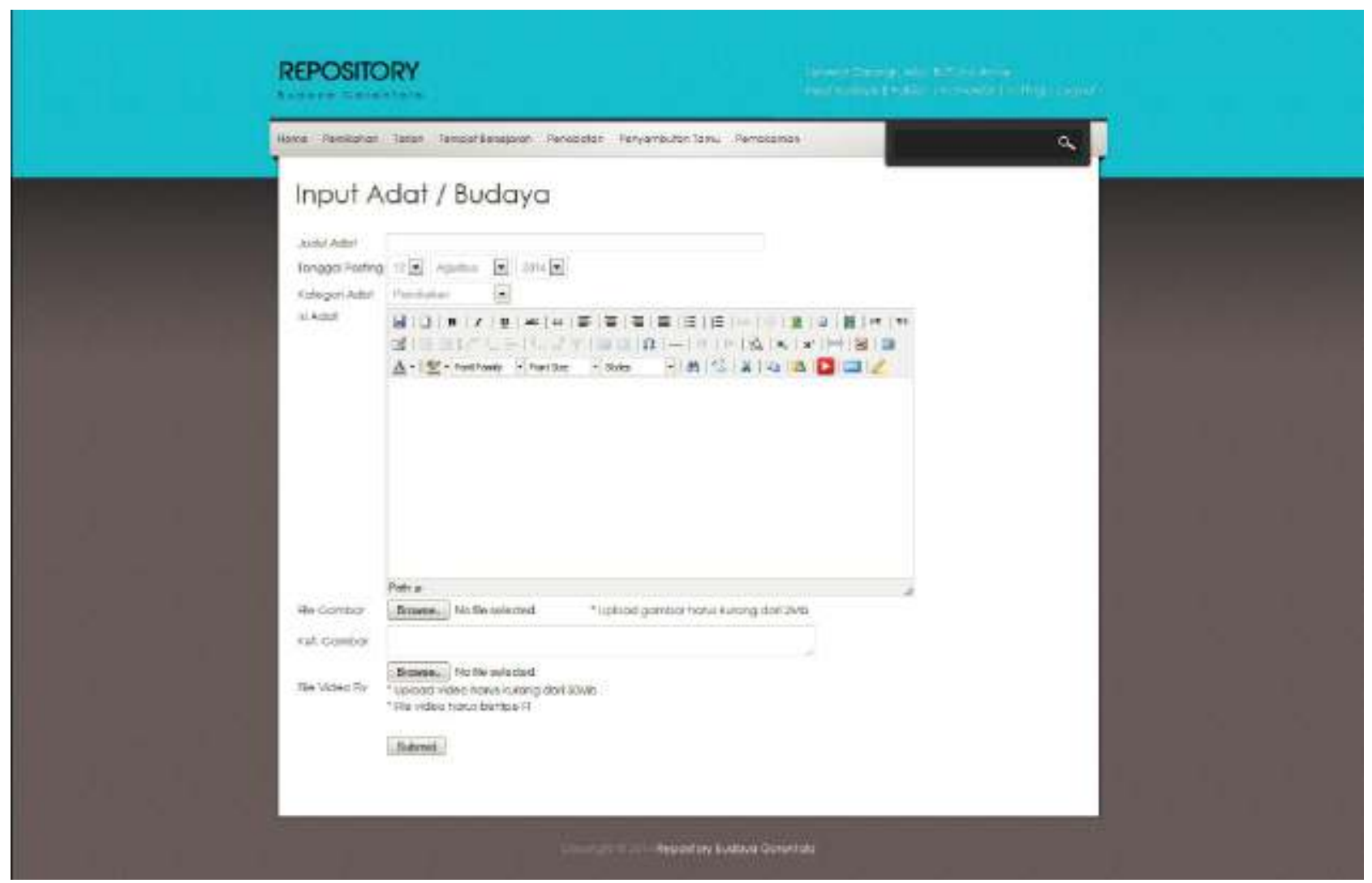

Figure 4. The page for cultural data input

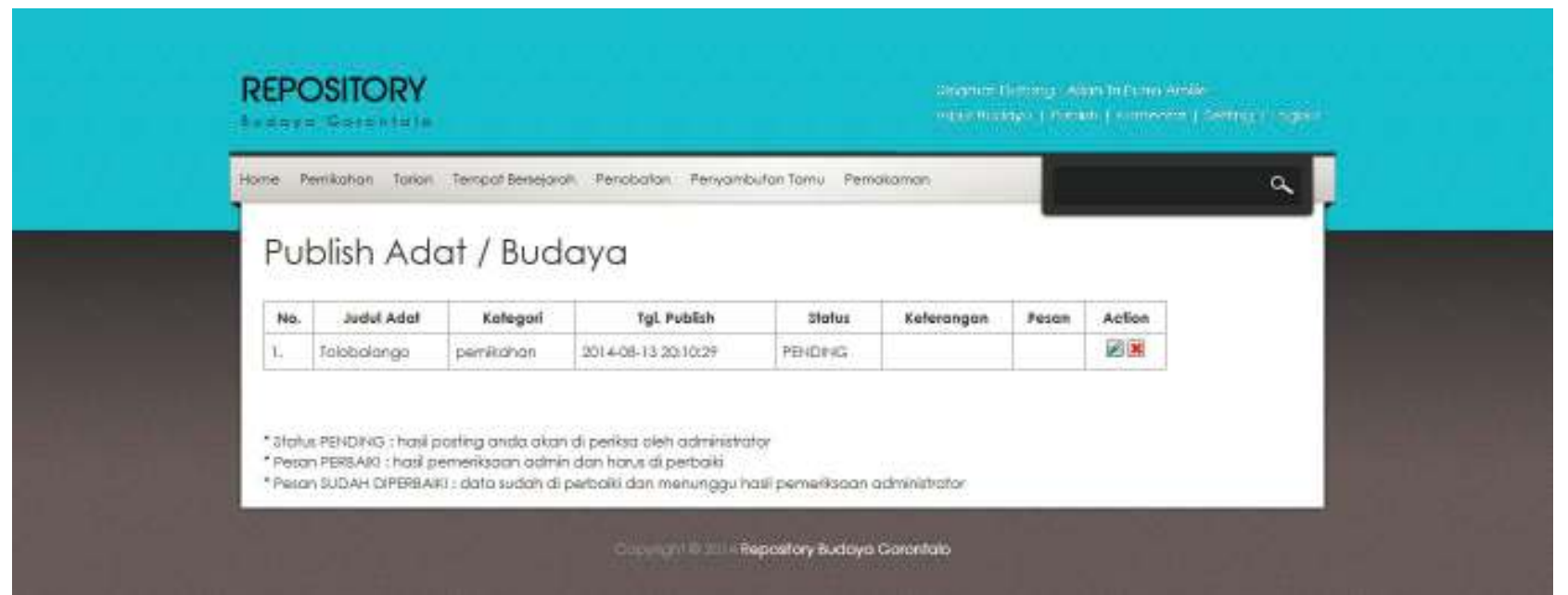

Figure 5. The page for list of cultural data contributor 


\section{Determining reviewer for data inputted by the contributor}

The second activity is carried out if there has been a cultural data stored into the system waiting to be reviewed (see Figure 6) to be determined further by the reviewer if the article is feasible or not to be published. In this activity, all the entered cultural data are then provided with reviewer by the application admin in accordance with the competence and knowledge of the Gorontalo culture (see Figure 7). The appointed reviewers, are taken from indigenous stakeholders, culturalists or anyone appointed by the government, which previously has been entered into the application by admin

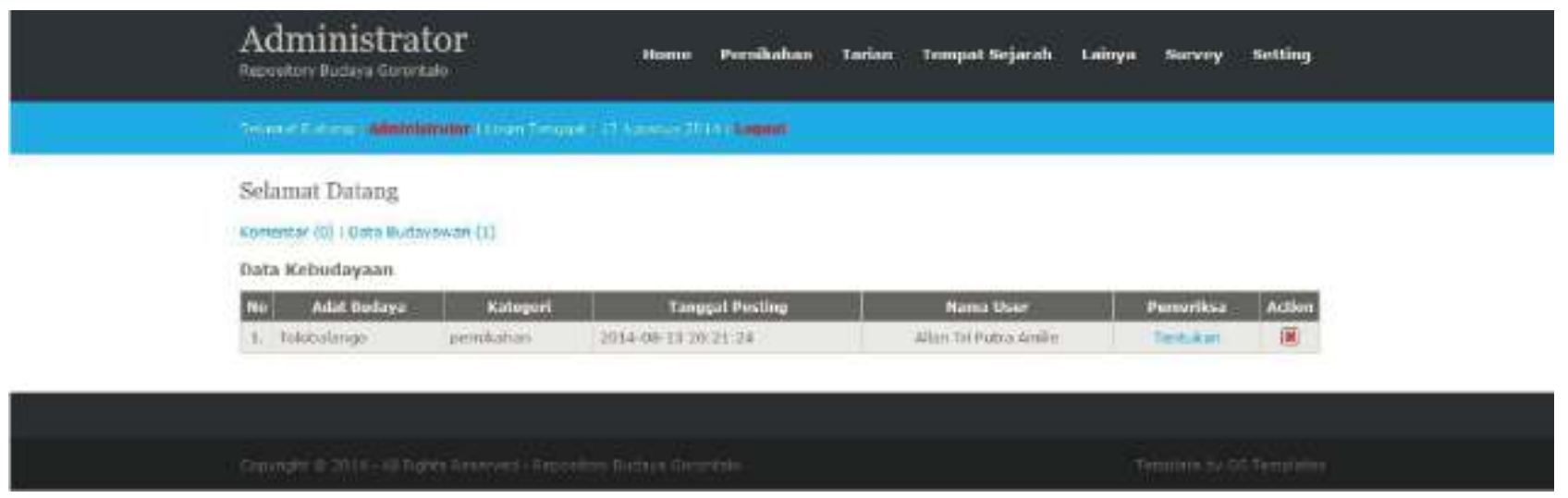

Figure 6. Page of list of articles from the contributor
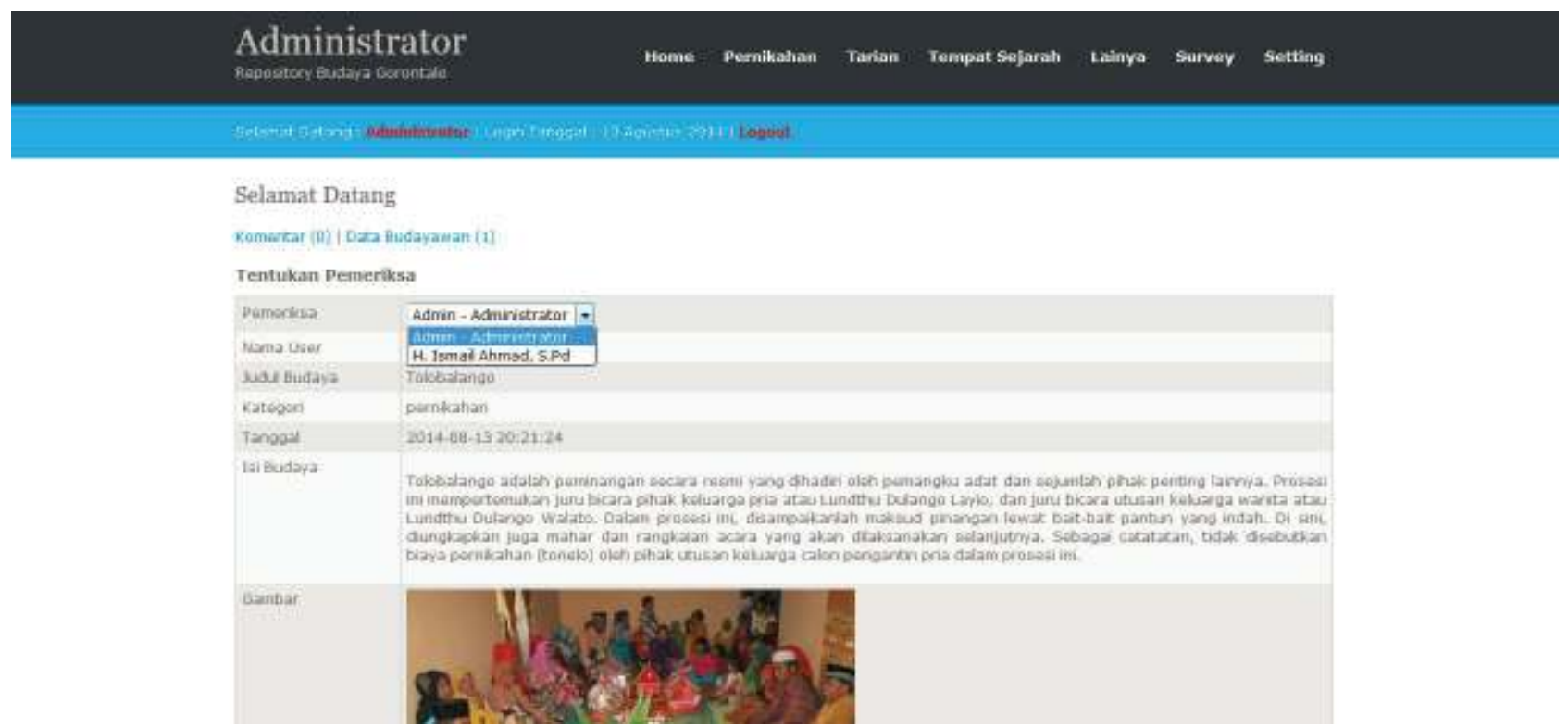

Figure 7. Page for reviewer determination 


\section{Reviewing the cultural data that has been entered in the application.}

The third activity, namely cultural data review (see Figure 8), all data entered by the contributor have been provided with reviewers by application admin, examined and determined by the reviewer whether it is feasible or not to publish. In this activity, the reviewer can see the entire list of cultural data that has been specified by the admin. To read the data, the reviewer can see the details of cultural data (either texts, images and videos), and then if they are deemed appropriate by the reviewer, the cultural data can be published, or if it is still in need of improvement, the reviewer will provide improvement information for cultural data that have been entered by the contributor to be repaired (see Figure 9). The disadvantage of the developed application is that the video format of the data on applications developed can only be played on browser computer desktop, cannot accommodate the mobile device, such as phone and tablet.

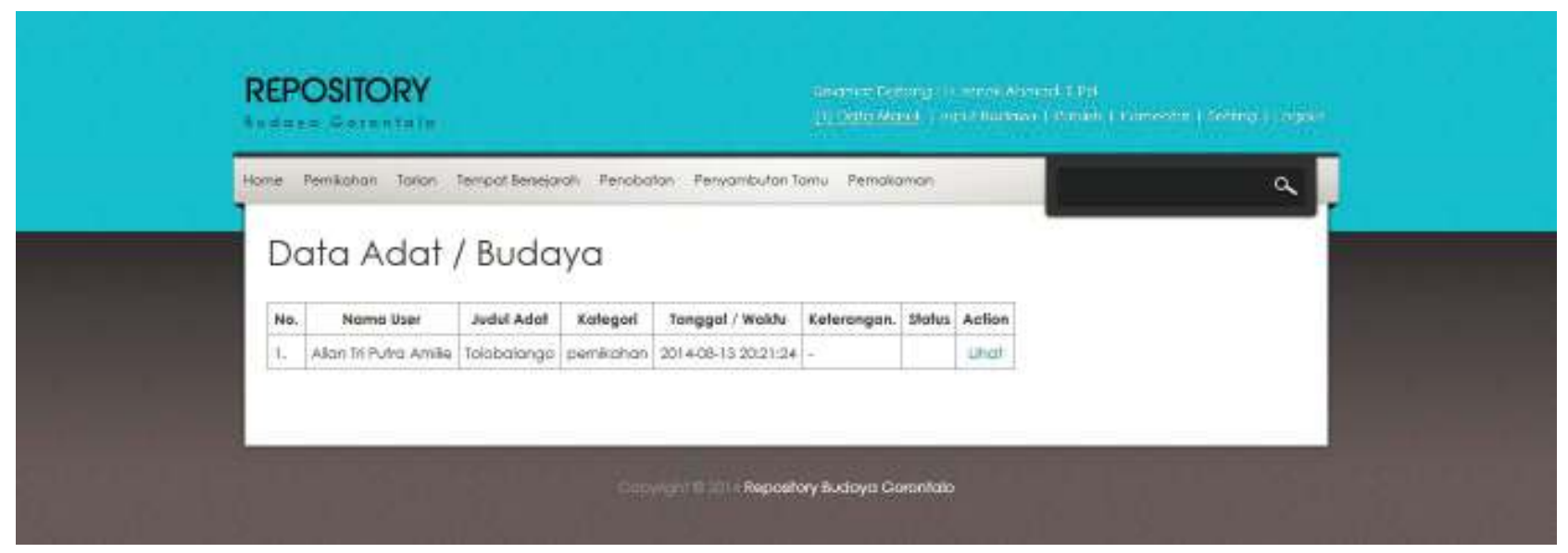

Figure 8. Page for list of articles to be reviewed

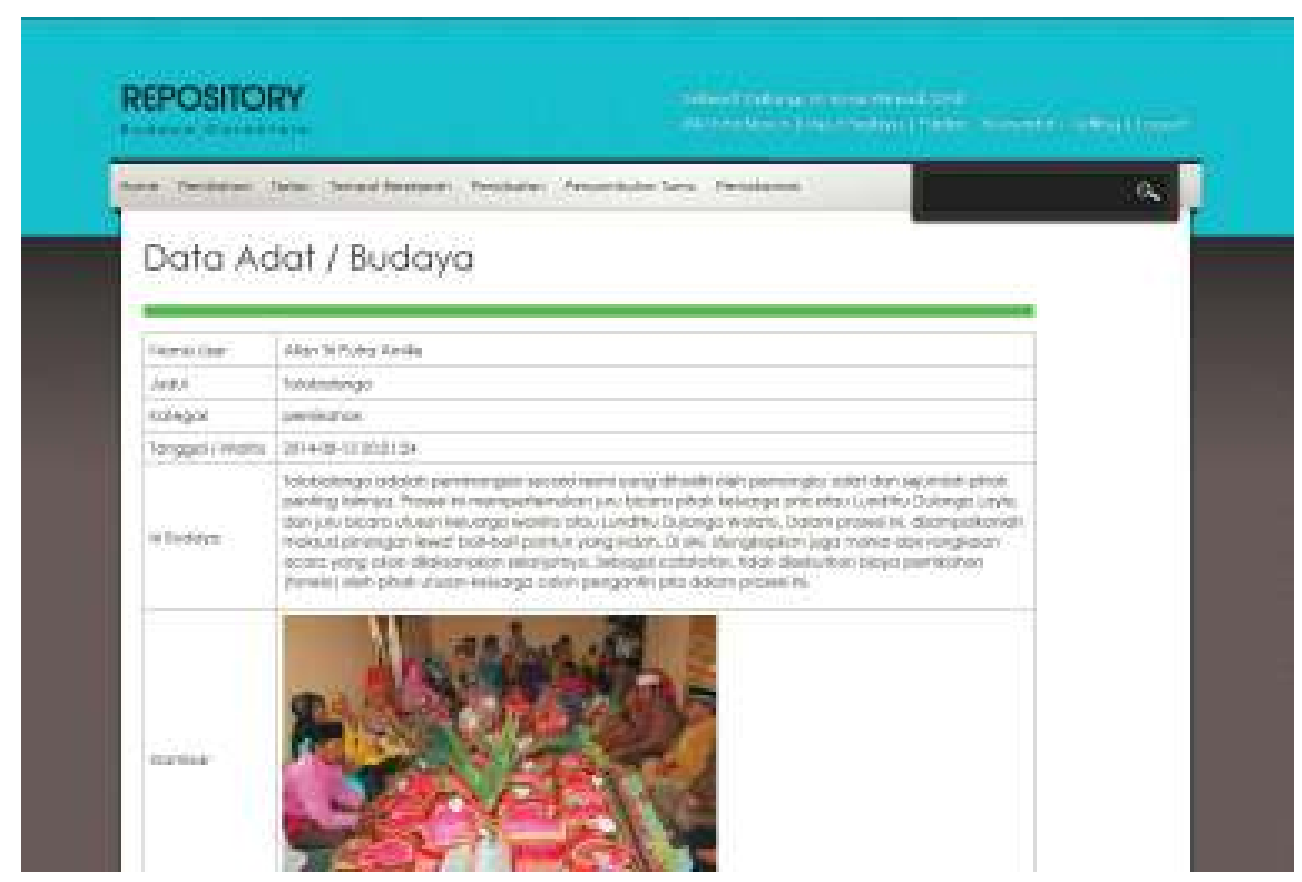

Figure 9. Page for reviewing article 


\section{CONCLUSION}

Based on the previous discussion several conclusions can be drawn, among others

a. One strategy for preservation and development of local culture in Gorontalo is through an application that can store and display the results of website -based digitization of local culture of Gorontalo called "Digital Repository of Gorontalo culture".

b. The application of digital repository developed contains data of Gorontalo local culture such as 4 aspects of Gorontalo customs, dances, historic sites and cultural artifacts. The application developed consists of three main activities including incorporating cultural data, specifying the reviewer and reviewing the data. This is intended that the truth of data entered by the contributor can be maintained.

c. Video format of cultural data on the developed application can only be played on browser computer desktop, and cannot accommodate mobile devices, such as phone and tablet. And thus video formats that can be played on the device are needed.

\section{REFERENCES}

Abdussamad, K., Dali, T., Tuloli, N., Dujo, D., Musa, T. A., Kasim, M. M., Polontalo, I., Mahdang, B. Y., dan Wahidji, H., (1985), Empat Aspek Budaya Gorontalo, PT. Aksara Indira Harapan, Jakarta.

Europeana Think Culture. Strategic Plan 2011 2015. [Online]. Available:

http://www.pro.europeana.eu/c/document_library/ get file? unid $=c 4 f 19464-7504-44 d b-a c 1 e-3 d d b 78 c$ 922d7\&groupId=10602 [Access: Juli. 1, 2015].

Lynch, C. A., (2003), Institutional Repositories: Essential Infrastructure for Sholarship in the Digital Age., ARL Bimonthly Report 226.,http://www.arl.org/bm doc/br226.pdf., diakses 30Juni 2015.

Mulyanto, A., Latief, M., Rohandi, M., Muslimin.,(2014),Sistem Informasi Repositori Digital Budaya Gorontalo., Conference on International Technology and Electrical Engineering., Yogyakarta.
Rini, F. Ikhsan, M., (2014), E-Library Pada Badan Perpustakaan Dan Arsip Daerah Provinsi Jambi., Prosiding KNSI, Makassar.

Pressman, Roger.,(2010), Software Engineering: A Practioner's Approach, 7th Edition. Mc Graw Hill International., USA.

Said, M., Firmawan, H., Purwaningsih, E., dan Sujana., (2009), Ensiklopedia Nukilan Kearifan Lokal Nusantara untuk Merevitalisasi Budaya Lokal dan Peradaban Bangsa Indonesia., Laporan Penelitian., Jakarta.

Sutjaja, I Gusti Made (downloader).,(2006), Endangered Languages of the World.

Sejarah dan Peradaban Gorontalo., http://www.gorontaloinfo.20megsfree.com/asb.html, diakses pada tanggal 2Juli 2015. 